\title{
Veliidae (Insecta, Heteroptera, Gerromorpha) from southeastern Brazil: three new species from Rio de Janeiro State, a new species group for Neotropical Rhagovelia Mayr, and notes on distribution and synonymy
}

\author{
Felipe Ferraz Figueiredo Moreiraㄹ, Julianna Freires Barbosa ${ }^{1} \&$ José Ricardo Inacio Ribeiro $^{2}$
}

\begin{abstract}
'Departamento de Zoologia, Laboratório de Entomologia, Instituto de Biologia, Universidade Federal do Rio de Janeiro, Avenida Brigadeiro Trompowski, s/n, bloco A, sala 107, Ilha do Fundão, Caixa Postal 68044, 21941-971 Rio de Janeiro-RJ, Brasil. felipento@hotmail.com; julianna.freires@gmail.com ${ }^{2}$ Universidade Federal do Pampa, Campus São Gabriel. Avenida Antônio Trilha 1847. Centro, 97300-000 São Gabriel-RS, Brasil. joseribeiro@unipampa.edu.br
\end{abstract}

\begin{abstract}
Veliidae (Insecta, Heteroptera, Gerromorpha) from southeastern Brazil: three new species from Rio de Janeiro State, a new species group for Neotropical Rhagovelia Mayr, and notes on distribution and synonymy. Microvelia nelsoni sp. nov., M. takiyae sp. nov., and Rhagovelia mangaratiba sp. nov. are described. Rhagovelia scitula and $R$. whitei are transferred from the robusta group to the new whitei group. Rhagovelia denticulata is synonymized under $R$. scitula. Microvelia longipes, Oiovelia brasiliensis, Rhagovelia sooretama, $R$. trianguloides, $R$. vaniniae, and Stridulivelia quadrispinosa are recorded for the first time from Rio de Janeiro State. Additional new municipality records in Rio de Janeiro State are presented for Microvelia braziliensis, $M$. ioana, M. mimula, M. pulchella, Paravelia basalis, P. itatiayana, Rhagovelia accedens, R. agra, R. aiuruoca, R. elegans, $R$. hambletoni, $R$. henryi, $R$. itatiaiana, $R$. lucida, $R$. macta, $R$. modesta, $R$. novana, $R$. scitula, $R$. tenuipes, $R$. tijuca, $R$. triangula, and $R$. zela. Corrections are presented for the previously published distributions of Rhagovelia aiuruoca, R. lucida, R. macta, and R. triangula.
\end{abstract}

KEYWORDS. Aquatic insects; Hemiptera; Neotropical Region; southeastern Brazil; taxonomy.

\begin{abstract}
RESUMO Veliidae (Insecta, Heteroptera Gerromorpha) do Sudeste do Brasil: três novas espécies do Estado do Rio de Janeiro, um novo grupo para espécies neotropicais de Rhagovelia Mayr, e notas sinonímicas e de distribuição. Microvelia nelsoni sp. nov., M. takiyae sp. nov. e Rhagovelia mangaratiba sp. nov. são descritas. Rhagovelia scitula e $R$. whitei são transferidas do grupo robusta para o novo grupo whitei. Rhagovelia denticulata é sinonimizada $\operatorname{com} R$. scitula. Microvelia longipes, Oiovelia brasiliensis, Rhagovelia sooretama, $R$. trianguloides, $R$. vaniniae e Stridulivelia quadrispinosa são registradas pela primeira vez no Estado do Rio de Janeiro. Ocorrências adicionais novas no Estado do Rio de Janeiro são apresentadas para Microvelia braziliensis, M. ioana, M. mimula, M. pulchella, Paravelia basalis, P. itatiayana, Rhagovelia accedens, $R$. agra, $R$. aiuruoca, $R$. elegans, $R$. hambletoni, $R$. henryi, $R$. itatiaiana, $R$. lucida, $R$. macta, $R$. modesta, $R$. novana, $R$. scitula, $R$. tenuipes, $R$. tijuca, $R$. triangula e $R$. zela. Correções acerca das distribuições de Rhagovelia aiuruoca, R. lucida, R. macta e $R$. triangula são apresentadas.
\end{abstract}

PALAVRAS-CHAVE. Insetos aquáticos; Hemiptera; Região Neotropical; Região Sudeste, taxonomia.

The water striders of the family Veliidae are small to medium sized heteropterans which spend most of their lifecycle skating over the surface of the water (Andersen 1982). They are predaceous insects, feeding mainly on small arthropods that swim up to the surface of the water, or that fall onto it and become trapped (Hungerford 1919). Certain species can be economically and medically important, acting as potential predators of anopheline larvae (Frick 1949) and pests (Nakasuji \& Dyck 1984).

The Veliidae, and the water bugs (Heteroptera, Gerromorpha, Leptopodomorpha, and Nepomorpha) as a whole, have been the target of recent intensive studies in Southeast Asia, which has lead to the description of many new species from that region (e.g., Hecher 2005; Zettel 2009; Yang \& Murphy 2011). Nevertheless, approximately $30 \%$ of the known species diversity of Gerromorpha is present on the Neotropical Region (Polhemus \& Polhemus 2008), and many species remain undescribed, especially in the subfamily Microveliinae (Veliidae) (Polhemus and Polhemus 2007).
The last comprehensive work concerning South American Gerromorpha is that of Heckman (2011) and the fauna from Rio de Janeiro State has been target of continuous taxonomic and faunistic studies (e.g., Moreira \& Ribeiro 2009; Ribeiro et al. 2010). New species and records are still being discovered, some of which are presented here, together with notes concerning species from other states of southeastern Brazil.

\section{MATERIAL AND METHODS}

All the localities are organized in north-to-south order. Names of collectors or depositories appear inside parenthesis. In listings of collection data, a comma separates label information, a semicolon separates specimens from the same general locality, but different collecting events, and a period mark separates information on different collecting localities.

Material from the following institutions was examined: Coleção Entomológica Prof. José Alfredo Pinheiro Dutra, 
Departamento de Zoologia, Instituto de Biologia, Universidade Federal do Rio de Janeiro, Rio de Janeiro, Brazil (DZRJ) and Museu Nacional, Universidade Federal do Rio de Janeiro, Rio de Janeiro, Brazil (MNRJ).

All measurements are given in millimetres. Abbreviations used for measurements are as follows: body length (BL), head length (HL), head width across the eyes (HW), length of antennomeres I-IV (ANT I, ANT II, ANT III, ANT IV), minimum interocular distance (INT), maximum eye width (EYE), pronotum length along longitudinal midline (PL), pronotum width (PW), length of foreleg segments (FORELEG), length of middle leg segments (MIDLEG), length of hind leg segments (HINDLEG), femoral length (FEM), tibial length (TIB), length of tarsomeres I-III (TAR I, TAR II, TAR III).

\section{RESULTS}

\section{Descriptions}

\section{Microvelia (Microvelia) nelsoni sp. nov.}

Apterous male. BL-1.74; HL-0.33; HW-0.54; ANT I-0.26, ANT II-0.18, ANT III-0.23, ANT IV-0.33; INT-0.28; EYE0.14; PL-0.31; PW-0.70; FORELEG: FEM-0.50, TIB-0.41, TAR I-0.21; MIDLEG: FEM-0.63, TIB-0.55, TAR I-0.11, TAR II-0.21; HINDLEG: FEM-0.61, TIB-0.73, TAR I-0.10, TAR II-0.23.

General body color black, with a transverse orange red mark on anterior portion of pronotum, in area between eyes. When dried, silvery pubescence visible on head (inner eye margin and median posterior portion), on sides of pronotum mark, sides of abdominal tergites I and III-V, and posterior area of abdominal connexiva on sides of segments III-VI (Fig. 1). Eyes dark red. Venter of head reddish brown. Rostrum brown, with distal segment dark brown. Acetabula reddish brown. Genital segments reddish brown. Coxae, trochanters and most of femora yellow; apex of femora, tibiae and tarsi brown.

Head slightly elongated, with eyes relatively small and a few long setae on base of rostrum, besides silvery pubescence. Antennae (Fig. 2) covered by short setae, with a few long, thin setae on dorsum of antennomere I. Antennomeres I wider than others, slightly curved outward, thickened towards apex; II thickened towards apex, at apex slightly wider than III; III cylindrical, thinner than IV; IV fusiform, on middle subiqual to II in width. Rostrum reaching base of mesosternum.

Pronotum covering most of thorax, leaving only metathoracic triangles exposed (Fig. 3). Circular punctuations present on a centrally interrupted transverse row adjacent to anterior margin of pronotum; another transverse row posterior to pronotum mark; and several sparse punctuations after last row. Venter of thorax without elaborated ornamentation.

Abdomen with sides bowed outward, wider between segments IV and V, covered by several short setae, besides areas marked by silvery pubescence. Posterior margin of abdominal tergite VII almost straight. Abdominal connexives slightly elevated. Genital segments well exposed. Abdominal sternites short (except for last one), with posterior margins concave, centrally depressed, without tubercles. Genital segment I dorsally without apical central notch, ventrally concave posteriorly. Proctiger without lateral projections (Figs. 4-5). Parameres symmetrical, elongated, curved, thin (Fig. 6).

Legs relatively elongated, without dilated articles, spines, or tubercles. Fore tibiae with grasping comb weakly developed into a curved spine, which extends slightly after apex of segment. Hind femora slightly thicker than mid femora. Hind tibiae straight.

Apterous female. BL-1.99; HL-0.26; HW-0.56; ANT I0.26, ANT II-0.19, ANT III-0.24, ANT IV-0.38; INT-0.31; EYE-0.14; PL-0.36; PW-0.79; FORELEG: FEM-0.54, TIB0.43, TAR I-0.24; MIDLEG: FEM-0.64, TIB-0.60, TAR I0.11, TAR II-0.23; HINDLEG: FEM-0.65, TIB-0.75, TAR I-0.13, TAR II-0.23.

Identical to male in coloration, including distribution of silvery pubescence. Body very similar to male, but more rounded. Posterior margin of abdominal tergite VII straight. Abdominal tergite VIII tapering posteriorly. Abdominal sternites slightly longer than in male, without central depression. Proctiger rounded, in horizontal position.

Type-material. BRAZIL: Rio de Janeiro - Rio de Janeiro, Floresta da Tijuca, Rio da Fazenda, 19.III.1995, (L. F. Dorvillé): 1 apterous male [HOLOTYPE], 1 apterous female [PARATYPE] (DZRJ).

Distribution. Known only from the type-locality

Etymology. Named in honor of Nelson Ferreira-Jr., entomologist and friend.

Discussion. Microvelia nelsoni sp. nov. is part of the group of species of Microvelia Westwood, 1834 in which the pronotum extends posteriorly covering most of the dorsum of thorax, and leaving only the posterolateral metathoracic triangles exposed. It is very similar to $M$. argentata Nieser \& Alkins-Koo, 1991, both possessing generally black body coloration, with an orange-red mark on the pronotum, and areas of silvery pubescence along the inner eye margin, the base of head, and the abdominal tergites and connexiva.

The silvery areas of the head and pronotum are practically identical in the two species, however, their distribution on the abdomen is different. In $M$. argentata, there are silvery setae on the sides of abdominal tergites II-IV, connexival segments II-III, and centrally on tergites V-VII. By contrast, in M. nelsoni sp. nov., the silvery areas occur on the sides of abdominal tergites I and III-V, and connexival segments III-VI, whereas there are no silvery areas centrally on tergites V-VII (Fig. 1). Microvelia argentata also displays an apicoventral tubercle on the fore femur, another tubercle on the last abdominal sternite, and a central notch on the posterior dorsal margin of abdominal segment I. None of these modifications are seen in $M$. nelsoni sp. nov., which also differs from $M$. argentata in regard to paramere shape (Fig. 6).

Microvelia argentata was described from Trinidad \& Tobago, and subsequently recorded from Argentina by Mazzucconi et al. (2008). Taking into consideration the strong general 
resemblance between males of $M$. argentata and $M$. nelsoni sp. nov., and also the large distance between geographical records of the former species, the specimens of M. argentata previously recorded from Argentina may eventually prove to be representatives of the above-described new species.

\section{Microvelia (Microvelia) takiyae sp. nov.}

Macropterous male. BL-1.48-1.51; HL-0.21-0.23; HW0.39-0.40; ANT I-0.15-0.16, ANT II-0.13, ANT III-0.140.15, ANT IV-0.25-0.26; INT-0.18-0.20; EYE-0.07-0.09; PL-0.43-0.50; PW-0.63-0.66; FORELEG: FEM-0.34-0.35, TIB-0.26-0.28, TAR I-0.15-0.18; MIDLEG: FEM-0.390.40, TIB-0.34-0.35, TAR I-0.06-0.08, TAR II-0.13-0.14; HINDLEG: FEM-0.43-0.46, TIB-0.48-0.50, TAR I-0.06, TAR II-0.13-0.14.

Head brown to dark brown, with longitudinal median line impressed, shining and darker, and a thin yellow stripe at base. Base of antennomere I yellow; remainder of segment I plus all other antennomeres light brown to dark brown. Eyes dark reddish brown. Rostrum light brown, except segment IV dark brown. Pronotum light brown to brown, with yellow stripe adjacent to head; yellow coloration extending laterally over propleura and acetabula. Sides of meso- and metathorax yellow. Venter of thorax orange-brown to dark-brown. Abdominal tergites yellow, with intersegmental areas brown. Abdominal connexives yellow, lighter than tergites. Venter of abdomen laterally yellow, centrally orange-brown to darkbrown, with intersegmental areas darker. Genital segments yellow. Wings, when closed and dried, brown, with veins black until shortly after apex of pronotum, then concolorous with wing; wings also slightly white at centre and apex. Coxae, trochanters and base of femora light-yellow; remainder of legs yellow to light brown.

Head covered by short setae, with some longer setae on base of rostrum. Antennae covered by short setae, with some longer setae on dorsum of antennomeres II-IV. Antennomere I slightly curved outward, wider than others, thickened up to apex; II wider than III and IV, thickened up to apex; III cylindrical, thinner than others; IV fusiform, wider than III. Rostrum reaching base of mesosternum.

Pronotum subpentagonal, covered by short black setae, with weak longitudinal median carina on posterior lobe, humeri slightly elevated with outer side rounded, and posterior angle rounded. Anterior lobe of pronotum with a centrally interrupted row of circular punctuations adjacent to anterior margin; another irregular row of punctuations separating anterior and posterior lobes. Posterior lobe of pronotum with several circular punctuations. Sides of thorax with some punctuations on intersegmental areas. Venter of thorax without elaborated ornamentation, only with punctuations bellow fore coxae and on intersegmental sulci.

Posterior margin of last abdominal tergite concave. Venter of abdomen with no carina, depressions or tubercles. Genital segments well exposed, with slight sinistral rotation when viewed posteriorly (Fig. 7). Dorsum of genital segment
I with lateral margins posteriorly divergent and posterior margin distinctly concave centrally (Fig. 8). Venter of genital segment I with no depressions or carina, posterior margin symmetrically concave, without central notch (Fig. 8). Genital segment II without ornamentation, posterior margin notched on both sides (Fig. 8). Proctiger without projections, lateral margins convergent and apex rounded. Parameres asymmetrical, the left larger than the right; both parameres with bases rounded; the right paramere thin and elongated, left paramere short (Figs. 9-10).

Wings slightly passing apex of body. Legs without spines, tubercles or other relevant modifications. Grasping comb weakly developed, projecting slightly beyond apex of fore tibia as a very short spine. Hind femora slightly wider then mid femora. Hind tibiae thin and straight.

Macropterous female. BL-1.65-1.74; HL-0.26-0.28; HW0.40-0.41; ANT I-0.15-0.16, ANT II-0.13, ANT III-0.140.15, ANT IV-0.26; INT-0.19-0.23; EYE-0.10; PL-0.53-0.55; PW-0.69-0.73; FORELEG: FEM-0.33-0.35, TIB-0.28-0.29, TAR I-0.16-0.19; MIDLEG: FEM-0.38-0.41, TIB-0.340.36, TAR I-0.08-0.09, TAR II-0.14; HINDLEG: FEM-0.440.49 , TIB-0.53-0.55, TAR I-0.06-0.08, TAR II-0.13-0.14.

Very similar to male in coloration and structure, but more robust and with venter of abdomen lighter. Genital segments exposed. Proctiger in horizontal position, with apex rounded.

Type-material. BRAZIL: Rio de Janeiro - Angra dos Reis, Ilha Grande, Rio da Cachoeira, 17.III.1991 (no collector data): 1 apterous male [HOLOTYPE], 9 macropterous males, 19 macropterous females [PARATYPES] (DZRJ). Angra dos Reis, Ilha Grande, Rio do Paredão, 20.III.1994, (no collector data): 1 macropterous female [PARATYPE] (DZRJ).

Distribution. Known only from small rivers on Ilha Grande, a costal island of preserved Atlantic Forest in southern Rio de Janeiro State.

Etymology. Named in honor of Daniela Maeda Takiya, entomologist and friend.

Discussion. Microvelia takiyae sp. nov. is very similar in general aspect to $M$. picinguaba Moreira \& Barbosa, 2011 and M. ubatuba Moreira \& Barbosa, 2011. Like these two species, $M$. takiyae sp. nov. does not display striking modifications to the legs or thorax, but has genitalic features that distinguish it from other species of the genus.

As described for $M$. picinguaba, males of M. takiyae $\mathbf{s p .}$ nov. also possess asymmetric external genitalia. The genital segments of both species are turned to the left, the rotation being stronger in $M$. picinguaba. In these two species, a central notch is also visible on the dorsal posterior margin of genital segment I, being more developed in M. takiyae sp. nov. (Fig. 8). By contrast, paired longitudinal carinae on the venter of the abdomen and an asymmetric excavation of the ventral posterior margin of genital segment I are only present in males of $M$. picinguaba. These differences, in addition to distinct paramere shapes (Figs. 9-10), differentiate the two species. Other known cases of genital asymmetry in Neotropical species of Microvelia were presented and compared by Moreira \& Barbosa (2011). 

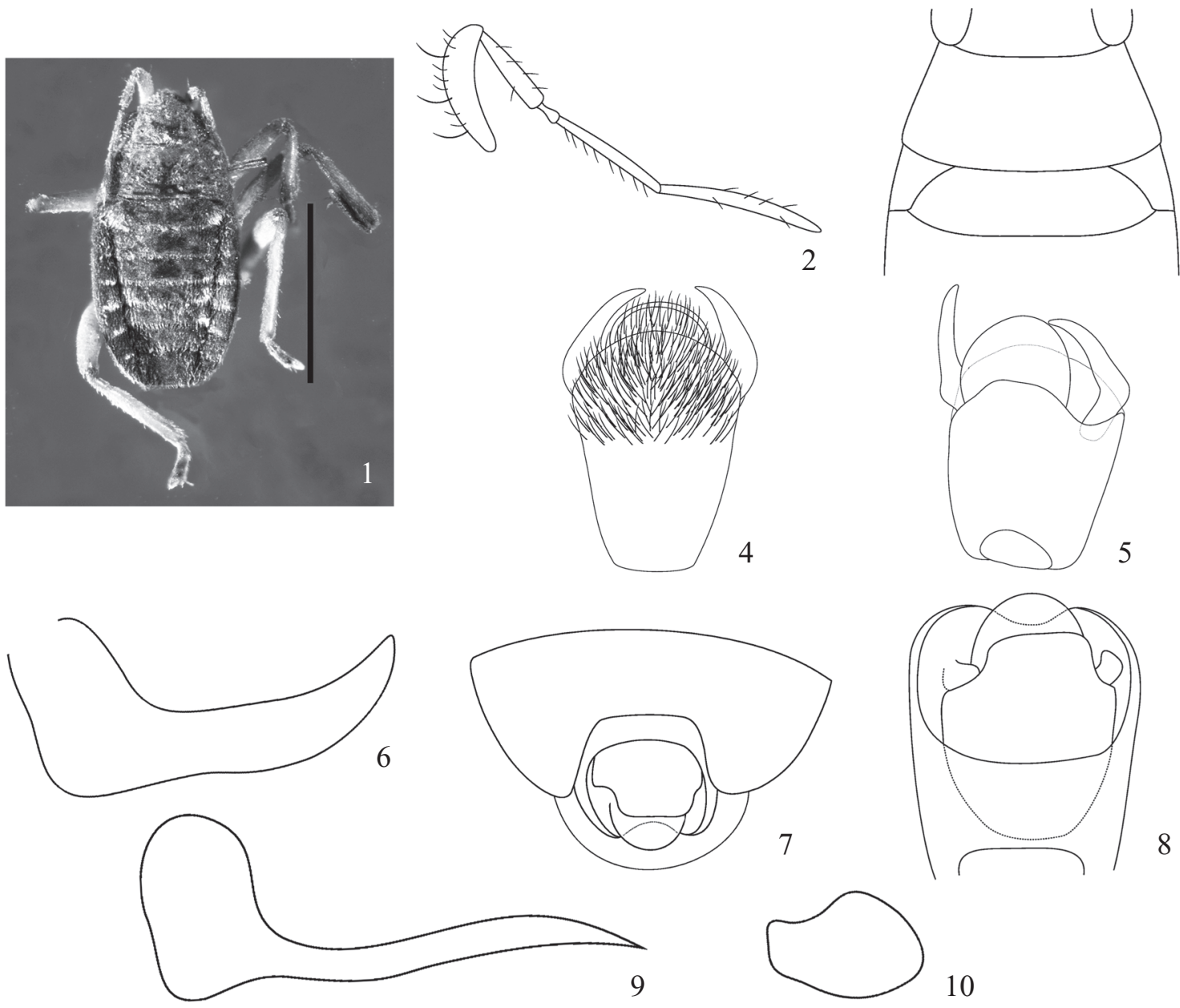

9

10

Figs. 1-10. Microvelia spp. 1-6. Microvelia nelsoni sp. nov. 7-10. Microvelia takiyae sp. nov. 1. Apterous male, dorsal view, genitalia removed. 2. Male antenna. 3. Apterous male, thorax and parts of head and abdomen, dorsal view. 4. Male genital segments II-III, dorsal view. 5. Male genital segments IIIII, ventrolateral view. 6. Male paramere. 7. Macropterous male, apex of body, parameres omitted. 8. Male genital segments I-III, parameres partially omitted. 9. Male left paramere. 10. Male right paramere.

Microvelia takiyae sp. nov. can be separated from $M$. ubatuba by the symmetrical genitalia in the latter species. In addition, males of M. ubatuba have the venter of genital segment I depressed, with a central notch on the posterior margin different in shape than that of M. takiyae sp. nov., and distinct paramere shape.

\section{Rhagovelia mangaratiba sp. nov.}

Apterous male. BL-5.38; HL-0.50; HW-1.11; ANT I-1.18, ANT II-0.64, ANT III-0.81, ANT IV-0.65; INT-0.33; EYE0.35; PL-1.24; PW-1.36; FORELEG: FEM-1.38, TIB-1.50, TAR I-0.08, TAR II-0.05, TAR III-0.36; MIDLEG: FEM-2.44, TIB-2.12, TAR I-0.14, TAR II-0.90, TAR III-0.90; HINDLEG: FEM-2.00, TIB-2.14, TAR I-0.14, TAR II-0.26, TAR III-0.43.

Head orange, with longitudinal median line and two curved marks at base darker, impressed and shining. Antennomeres I yellow at base, brown on most of its length, dark brown at apex; segments II-IV dark brown. Eyes reddish brown. Rostrum orange brown, except segment IV dark brown. Pronotum orange, lighter on lateral areas of anterior lobe, with margins brownish. Remainder of dorsum and sides of thorax orange brown. Venter of thorax orange, slightly lighter than dorsum. Abdominal tergites I-III orange; remaining tergites orange brown. Abdominal connexives orange brown, darker on inner portion. Abdominal sternites brown centrally, orange-brown on sides. Genital segment I brown on dorsum and ventral posterior margin; sides and rest of venter dark yellow. Coxae, trochanters and venter of femora dark yellow. Dorsum of fore and mid femora brown. Dorsum of hind femora orange-brown, except for dark brown apex. Tibiae brown, with distal third dark brown. Fore and mid tarsi dark brown; hind tarsi orange-brown, with apex of tarsomere III dark brown.

Head relatively short, with large eyes, covered by short brown setae, these setae more dense in the region ahead of eyes. Antennae covered by short brown setae, intermixed with longer more robust setae on dorsum and sides of antennomere I and dorsum of II. Antennomere I curved, wider after middle; II-III cylindrical, II at apex slightly wider than III; IV fusi- 
form, at middle slightly wider than III. Rostrum reaching base of mesosternum.

Pronotum long, completely covering mesonotum, with lateral margins slightly constricted between anterior and posterior lobes (Fig. 11). Anterior lobe of pronotum slightly swollen centrally, with a row of circular punctuations adjacent to anterior margin; another irregular row of punctuations between anterior and posterior lobes. Posterior lobe of pronotum without evident median carina, with several irregularly placed circular punctuations and posterior angle widely rounded (Fig. 11). Sides and venter of thorax without distinct ornamentation, with some punctuations on intersegmental areas and a pair of oblique rows of light long setae on mesosternum.

Abdominal tergites and connectives covered by short setae, without differentiated groups of setae or pubescence. Abdominal tergites I-III slightly swollen; remaining tergites flattened. Posterior margin of last abdominal tergite slightly curved. Abdominal connectives horizontal. Abdominal sternites separated by deep, glabrous and shining areas, more evident laterally. Last abdominal sternite with a pair of tubercles on sides of median region, this being distinctly flattened (Figs. 12-13). Posterolateral margins of last abdominal segment surrounding genital cavity without black denticles. Proctiger as in Fig. 14. Parameres symmetrical, robust, with inferior margin strongly expanded and apex turned upward (Fig. 15).

Legs covered by short brown setae and rows of longer black setae on femora and tibiae; fore tibia also with a dense patch of thick brown setae on venter. Tibial grasping comb well developed. Mid leg without evident modifications. Hind trochanter with 13-15 obtuse spinules placed in three irregular rows (Fig. 16). Hind femora centrally thickened, with 23 obtuse spinules followed by two longer and acute spines on proximal half; distal half with a ventralmost row of 12 short spines, and a dorsalmost row with a long acute spine followed by 6-7 progressively smaller spines (Fig. 16). Hind tibiae straight, with ventral row of short spines and straight apical spur.

Type-material. BRAZIL: Rio de Janeiro - Mangaratiba, Reserva Ecológica Rio das Pedras, Rio Grande, 15.III.2001, (Equipe Entomológica): 1 apterous male [HOLOTYPE] (DZRJ).

Distribution. Known only from the type-specimen, collected on a private area of Atlantic Forest on southern Rio de Janeiro State.

Etymology. Named after the municipality where the typespecimen was collected.

Discussion. Rhagovelia mangaratiba sp. nov. is part of the hirtipes group sensu Polhemus (1997), based on the long pronotum, which completely covers the mesonotum (Fig. 11); the posterolateral margins of the last abdominal segment lacking black denticles; the apical spur of hind tibia straight; and the shape of the male paramere (Fig. 15). This last feature is fundamental to distinguish $R$. mangaratiba sp. nov. from species of the robusta complex sensu Polhemus (1997), since there are no females available in order to check the presence or absence of a longitudinal carina on the dorsal abdomen.

Among species of the hirtipes group, $R$. mangaratiba $\mathbf{s p .}$ nov. is more similar to $R$. henryi Polhemus, 1997 and $R$. teresa Moreira, Nessimian \& Rúdio, 2010, due to the uniform orange color of the body. The remaining species of the group present generally dark coloration, with contrasting orange marks. The presence of a pair of tubercles on the last abdominal sternite of $R$. mangaratiba sp. nov. (Figs. 12-13) differentiates it from all other species in the group, and the occurrence of such structures in this position is unknown in any other species of the genus ever studied by the authors of the present work. Other diagnostic characteristics of $R$. mangaratiba sp. nov. are the hind trochanter with spinules placed in irregular rows (Fig. 16) and the male paramere shape (Fig. 15).

\section{Taxonomic notes}

\section{Rhagovelia group whitei, new species group}

In his revision and phylogenetic analysis of the Rhagovelia Mayr, 1865 from the Western Hemisphere, Polhemus (1997) defined the robusta complex for the Neotropical species of the genus with the following features: (1) pronotum of apterous forms with length on midline equal or greater than three times exposed portion of mesonotum, generally covering all of the mesonotum; (2) posterolateral margins of abdominal segment VII surrounding genital cavity without black denticles; (3) pronotum of macropterous females not projecting posteriorly; and (4) female middle femur cylindrical.

The robusta complex sensu Polhemus (1997) unites three species groups: hirtipes, elegans and robusta. All included species in these groups have the above mentioned characteristics, except for two species of the robusta group: $R$. scitula Bacon, 1956 and $R$. whitei (Breddin, 1898). Representatives of both species disagree with feature (2) mentioned above, and bear large black denticles on the area surrounding the genital cavity.

Such denticles are probably a case of parallelism or convergent evolution in relation to the collaris complex, in which most members of the included species groups display the same feature, except for members of the Caribbean tayloriella group, in which they have either been lost, or the plesiomorphic condition of absence retained (Dr. D. A. Polhemus, personal communication).

Besides the black denticles near the genital cavity, $R$. scitula and $R$. whitei also share putative synapomorphies not seen in any other species of the robusta group, or the robusta complex as a whole. The sides of thorax and most of the venter of the bodies in males and females of the two species are densely covered by black denticles shorter than those on posterior margin of segment VII, the male hind femur is enormously incrassate and ventrally flattened, and the male hind tibia is strongly curved and dorsoventrally flattened. Such shared features could support the hypothesis that $R$. scitula and $R$. whitei are sister-species, as proposed by Polhemus (1997). 

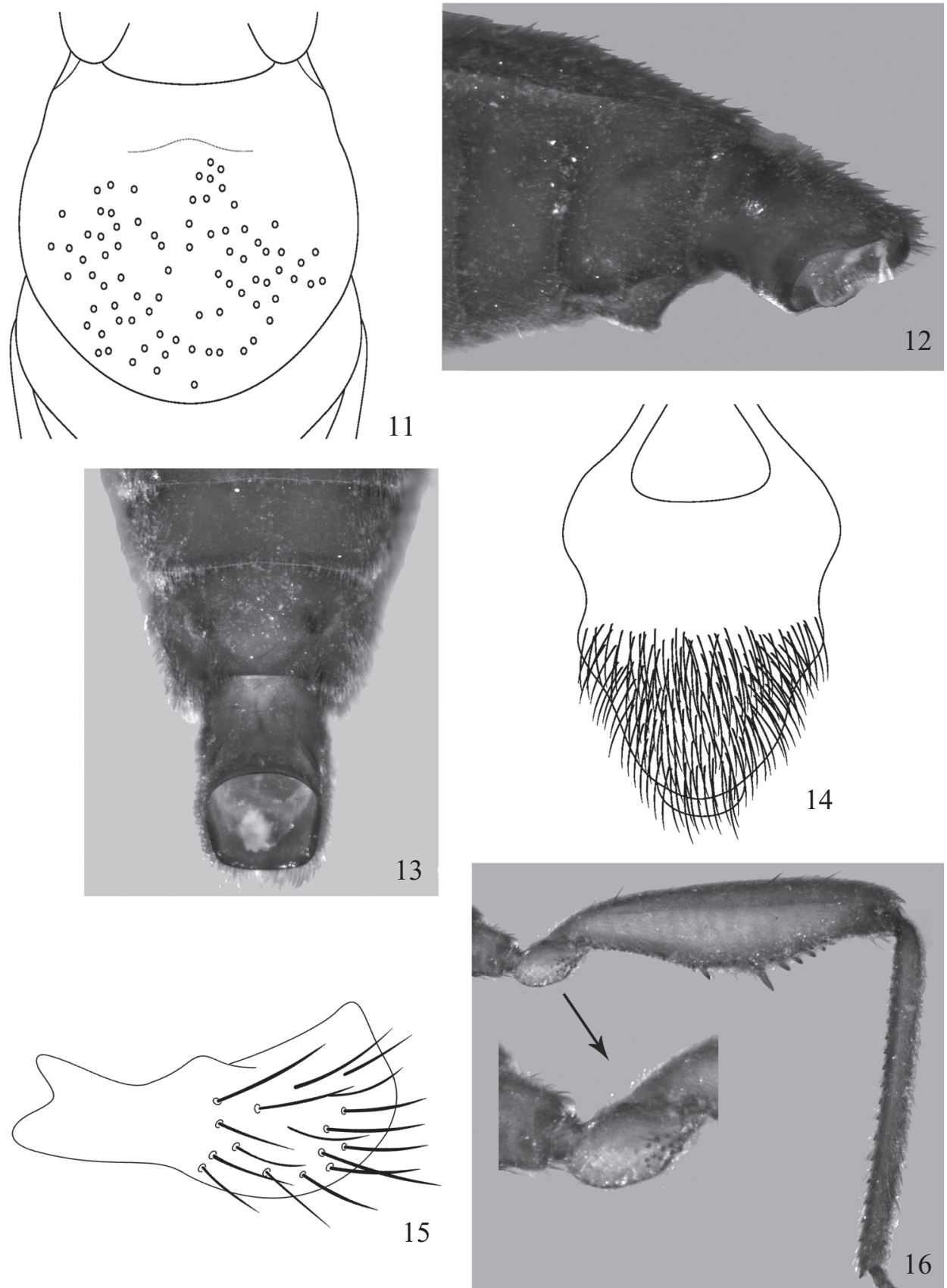

Figs. 11-16. Rhagovelia mangaratiba sp. nov. 11. Apterous male, thorax and parts of head and abdomen, dorsal view. 12. Apterous male, apex of body, lateral view, genital segments II-III removed. 13. Apterous male, apex of body, ventral view, genital segments II-III removed. 14. Male proctiger. 15. Male paramere. 16. Male hind leg and detail of hind trochanter.

With this in mind, and aiming a better arrangement of the species groups of Neotropical Rhagovelia, we propose the creation of the whitei group, within the robusta complex, uniting the two species discussed above. With the creation of this group, we also propose a modification of the key to species complex and groups of Polhemus (1997), starting from couplets 9 and 15 :

9. Posterolateral margins of abdominal segment VII surrounding genital cavity usually with large black denticles (usually numerous, but present only in small number in $R$. citata, and secondarily lost in the tayloriella group); if denticles absent then connexiva strongly convergent after abdominal segment III (species from the Caribbean Islands); macropterous females usually with an elevated posterior projection at the apex of the pronotum (absent in the varipes group); female middle femur often flattened ventrally on basal $1 / 3$..... 10

-. Posterolateral margins of abdominal segment VII surrounding the genital cavity usually without black denticles (present on the whitei group); macropterous females with 
posterior apex of the pronotum broadly angulated, not projected posteriorly; female middle femur cylindrical, not flattened on basal $1 / 3$..... 15

15. Posterolateral margins of abdominal segment VII surrounding genital cavity with large black denticles; venter of body densely covered by black denticles, shorter than those near the genital cavity; hind trochanter usually bearing a single long spine, greater than any of the spines on the hind tibia whitei group

-. Posterolateral margins of abdominal segment VII surrounding genital cavity without black denticles (in three species of the robusta group there are small denticles on sides of abdominal sternite VII, but not on posterolateral margins of segment); venter of body not densely covered by black denticles; hind trochanter unarmed, or bearing one or more short spines smaller or subiqual in size to the spines on the hind tibia, or bearing several spines of which one is much larger than the others ...... 16 [hirtipes, elegans and robusta groups]

\section{Rhagovelia scitula Bacon, 1956}

Rhagovelia denticulata Moreira, Nessimian \& Rúdio, 2010 (SYN. NOV.)

Unaware of the unique features of $R$. scitula and $R$. whitei, Moreira, Nessimian \& Rúdio (in: Moreira et al. 2010) described $R$. denticulata from Espírito Santo State, based mainly on the presence of black denticles on venter of body and the highly modified male hind leg, and assigned it to the varipes group.

The proper placement of $R$. denticulata is in the new white group, and based on the distribution of denticles on the venter of the thorax, and shape and distribution of spines on male hind leg, it must fall as synonym of $R$. scitula. After the description of $R$. denticulata, it was subsequently recorded from São Paulo State by Moreira \& Barbosa (2011), a record that must be assigned to $R$. scitula instead. An additional record of $R$. scitula from Rio de Janeiro State is presented below.

Examined material. BRAZIL: Rio de Janeiro - Macaé, Curubixás de Cima, Rio Curubixás, 22¹1’38.10”S, 4204’26.10”W, 21.III.2009, (G. Lefebrve \& V. P. Alecrim): 1 apterous female (DZRJ).

\section{Distributional notes}

\section{Microvelia braziliensis McKinstry, 1937}

This species was described based on material from "Rio de Janeiro", without mention of any specific locality. Subsequently, it was recorded from several localities in South America, but no other specimens from the state have been recorded so far.

Examined material. BRAZIL: Rio de Janeiro - Nova Iguaçu, poça na trilha próxima ao Rio Santo Antônio, 07.I.2010, (F. F. F. Moreira \& B. Clarkson): 4 apterous males, 6 apterous females (DZRJ).

\section{Microvelia ioana Drake \& Hottes, 1952}

Microvelia ioana was described from "Rio de Janeiro", and recently recorded from eastern São Paulo (Moreira \& Barbosa 2011). Additional specimens from Rio de Janeiro State are herein reported.

Examined material. BRAZIL: Rio de Janeiro - Itatiaia, Parque Nacional do Itatiaia, afluente de primeira ordem do Rio Campo Belo, 22 $25^{\circ} 50.36^{\prime}$ 'S, 4437'16.41'”, 15.IV.2007, (L. L. Dumas \& A. P. M. Santos): 1 apterous male, 2 apterous females (DZRJ). Teresópolis, Rio Comari (nascente), 24.XI.1991: 2 apterous males, 5 apterous females (DZRJ). Teresópolis, Rio Paquequer, VII.1991, (J. L. Nessimian): 1 apterous male (DZRJ). Teresópolis, Parque Nacional da Serra dos Órgãos, 13.V.2005, (J. L. Nessimian, A. L. H. Oliveira, A. M. Sanseverino): 19 apterous males, 43 apterous females (DZRJ); Parque Nacional da Serra dos Órgãos, primeira ponte após alojamento, 03.VII.2004, (F. F. F. Moreira): 8 apterous females, 1 apterous male (DZRJ); Parque Nacional da Serra dos Órgãos, afluente do Rio Paquequer, represado, 03.VII.2004, (F. F. F. Moreira): 1 apterous male (DZRJ). Nova Friburgo, Lumiar, tributário do Rio Santiago, 22²1'05.60”S, 42²2’31.60"W, 05.IV.2009, (V. P. Alecrim): 1 apterous female (DZRJ). Rio de Janeiro, Parque Nacional da Tijuca, Boca Do Lobo, caminho do Pico do Papagaio, 16.II.1991, (E. R. Silva): 1 apterous male (DZRJ). Angra dos Reis, Ilha Grande, 19.II.1992, (E. Calil): 1 apterous male (DZRJ); Ilha Grande, caminho entre palmares e o hotel, 19.II.1992, (E. R. Silva, J. R. Pereira, J. L. Nessimian): 4 apterous males, 2 apterous females (DZRJ).

\section{Microvelia longipes Uhler, 1894}

This species has a wide distribution in the Neotropical Region, and is herein recorded for the first time from Rio de Janeiro State.

Examined material. BRAZIL: Rio de Janeiro - Itaocara, Sítio Bom Sossego, brejo, 24.VI.2004, (F. F. F. Moreira): 1 apterous female (DZRJ). Itatiaia, Penedo, poças artificiais com macrófitas, 01.I.2007, (F. F. F. Moreira \& V. P. Alecrim): 15 apterous males, 3 macropterous males, 17 apterous females (DZRJ). Miguel Pereira, Ramada, piscina, 15.II.2010, (V. P. Alecrim \& V. P. Alecrim): 4 apterous males, 1 macropterous male, 1 macropterous female (DZRJ).

\section{Microvelia mimula White, 1879}

Microvelia mimula was recorded from Rio de Janeiro State by Ribeiro et al. (2010), without mention of a specific locality. The material examined by those authors was collected in the Maricá Municipality in several occasions, and specimens from São Fidélis, Macaé, Seropédica and Rio de Janeiro municipalities have been examined subsequently.

Examined material. BRAZIL: Rio de Janeiro - São Fidélis, Sítio São Geraldo, córrego/charco, 07.II.2009, (A. P. M. Santos, F. F. F. Moreira, N. Ferreira-Jr. \& R. B. Braga): 2 macropterous males, 1 macropterous female (DZRJ). Macaé, Rio Macaé, 16.IV.2009, (N. Ferreira-Jr.): 1 macropterous male (DZRJ). Seropédica, Estrada Rio-São Paulo, km 47, 5.II.1944, (Wygo.): 3 macropterous males, 1 macropterous female (MNRJ); 1.III.1944: 3 macropterous males, 3 macropterous females (MNRJ); II.1945: 1 macropterous male, 3 macropterous females (MNRJ). Rio de Janeiro, D. F., 21.I.1946, (Wygo.): 3 apterous males, 2 apterous females (MNRJ). Maricá, 16.X.1982: 1 macropterous m ale (DZRJ); 26.X.1987, (M. M. Souza): 1 macropterous male (DZRJ); 13.XI.1992, (J. L. Nessimian): 1 apterous male (DZRJ). 


\section{Microvelia pulchella Westwood, 1834}

Microvelia pulchella is one of most widely distributed gerromorphan bugs, and was recorded for the first time from Rio de Janeiro State by Ribeiro et al. (2010). Other records not mentioned on the same paper are presented here.

Examined material. BRAZIL: Rio de Janeiro - Itatiaia, estrada para Visconde de Mauá, poça, 16.XII.2006, (F. F. F. Moreira, R. B. Braga \& V. P. Alecrim): 1 macropterous male (DZRJ). Itatiaia, Penedo, poças artificiais com macrófitas, 01.I.2007, (F. F. F. Moreira \& V. P. Alecrim): 12 apterous males, 2 macropterous males, 7 apterous females, 5 macropterous females (DZRJ). Miguel Pereira, Ramada, piscina, 15.II.2010, (V. P. Alecrim \& V. P. Alecrim): 1 macropterous male, 2 macropterous females (DZRJ). Seropédica, Estrada Rio-São Paulo, km 47, 6-23.XII.1943, (Wygo.): 8 macropterous males, 8 macropterous females (MNRJ). Angra dos Reis, Ilha Grande, Praia da Parnaioca, poça e água corrente no costão, 29.XII.2008, (F. F. F. Moreira \& V. P. Alecrim): 16 apterous males, 2 macropterous males, 27 apterous females, 4 macropterous females (DZRJ).

\section{Oiovelia brasiliensis Moreira, Nessimian \& Rúdio, 2010}

This species was recently described from Espírito Santo, and later recorded from São Paulo by Moreira \& Barbosa (2011). Its presence in Rio de Janeiro is herein reported for the first time, and represents the first species of the genus known from the state.

Examined material. BRAZIL: Rio de Janeiro - Teresópolis, Vale da Revolta, 11.I.1990, (S. Potsch): 100 apteorus and macropterous males and females (DZRJ). Teresópolis, Rio Paquequer, 19.X.1991: 3 macropterous males, 1 macropterous female (DZRJ). Teresópolis, Serra do Subaio, Hotel Sayonara, 15.VIII.1996, (Nessimian \& Araújo): 1 macropterous male, 1 apterous female (DZRJ). Nova Friburgo, Rio Caledônia, 01.XII.1991: 1 apterous male (DZRJ). Nova Friburgo, Rio Cascatinha: 1 macropterous male (DZRJ); Rio Cascatinha, segunda ordem, 06.IV.1997: 3 macropterous males, 4 macropterous females (DZRJ). Nova Friburgo, Macaé de Cima, $22^{\circ} 25^{\prime} 51.90^{\prime \prime}$, 42॰32'18.90”'W, 30.XI.2008, (N. Ferreira-Jr.): 3 macropterous males, 1 apterous female, 1 macropterous female (DZRJ); Rio Macaé, ponte, 22²3'29.70" S, 42²9’06.00”W, 01.XII.2008, (B. H. L. Sampaio): 1 macropterous male (DZRJ). Nova Friburgo, Fazenda São Sebastião, Rio Bonito, 22²4'18.80”S, 42 27 '55.30”W, 01.XII.2008, (B. H. L. Sampaio): 1 macropterous male (DZRJ). Nova Friburgo, Macaé de Cima, Rio das Flores, 22²4’36.30”S, 42॰29'40.60”'W, (B. H. L. Sampaio): 2 macropterous females (DZRJ). Nova Friburgo, Macaé de Cima, 22²4’46.00”'S, 42³1'16.20”W, 12-13.IX.2009, (V. P. Alecrim): 8 macropterous males, 6 macropterous females (DZRJ). Angra dos Reis, tributário do Rio Bracuí, 17.III.2001: 2 apterous males (DZRJ). Mangaratiba, Reserva Ecológica Rio das Pedras, 15.V.2004, (R. B. Braga): 1 apterous female (DZRJ); Reserva Ecológica Rio das Pedras, Rio Grande, 13.VI.1999, (C. Ostrowski): 1 apterous male, 1 apterous female (DZRJ); 14.V.2000 (Entomologia): 1 apterous male, 1 apterous female (DZRJ).

\section{Paravelia basalis (Spinola, 1837)}

This species is known from São Paulo and Rio de Janeiro States (Moreira \& Barbosa 2011), and is herein recorded for the first time from Teresópolis, Itatiaia, Nova Iguaçu, and Angra dos Reis municipalities.

Examined material. BRAZIL: Rio de Janeiro - Teresópolis, Parque Nacional da Serra dos Órgãos, 1500-1700 m, 16-22.IV.1947, (Wygo.): 1 macropterous male (MNRJ). Itatiaia, XI.1950, (Travassos \& Dalcy): 2 ma- cropterous males (MNRJ). Nova Iguaçu, Tinguá, (Newton Santos): 2 macropterous males, 2 macropterous females (MNRJ); Represa Boa Esperança, 25.I.1957 (Santos \& Machado): 1 macropterous male, 1 macropterous female (MNRJ); 9.X.1960, (Evangelistas): 4 macropterous male, 5 macropterous females (MNRJ). Rio de Janeiro, (Dario Mendes): 1 macropterous female (MNRJ). Rio de Janeiro, Tijuca: 1 macropterous female (MNRJ). Rio de Janeiro, Pedra da Gávea, 21.V.1977, (Sergio P. C. Silva): 2 macropterous males, 1 macropterous female (MNRJ). Rio de Janeiro, Corcovado, VIII.1935, (M. S. Lopes): 2 macropterous males (MNRJ); 25.XI.1952, (Zajciv): 1 macropterous male, 2 macropterous females (MNRJ); X.1975, (C. A. Campos Seabra): 4 macropterous females (MNRJ). Angra dos Reis, Jussaral, X.1934, (Travassos \& Lopes): 5 macropterous male, 7 macropterous female (MNRJ); (D. Mendes): 6 macropterous males, 3 macropterous females (MNRJ).

\section{Paravelia itatiayana (Drake, 1951)}

Representatives of this species are found in bromeliad tanks, in the states of São Paulo and Rio de Janeiro. The known geographical distribution of this species in the second state is herein expanded, since it was previously recorded only from the municipalities of Itatiaia and Rio de Janeiro (Moreira \& Barbosa 2011).

Examined material. BRAZIL: Rio de Janeiro - Macaé, Ilha do Santana, bromélia, 20.X.1986, (A. L. Carvalho): 1 macropterous male, 1 macropterous female (DZRJ). Mangaratiba, Reserva Ecológica Rio das Pedras, bromélia, 22.V.2005, (D. Kaplan, M. T. A. Santos, L. Villaverde): 1 macropterous male (DZRJ). Maricá, Bromélia (C. Ostrovski): 3 macropterous males, 5 macropterous females (DZRJ).

\section{Rhagovelia accedens Drake, 1957}

Rhagovelia accedens is common in mountainous areas of the four states in southeastern Brazil. Here we present a new record from the Macaé River Basin, Nova Friburgo Municipality.

Examined material. BRAZIL: Rio de Janeiro - Nova Friburgo, Macaé de Cima, 22²5'27.50”'S, 42³2'08.40”W, 29.XI.2008, (N. Ferreira-Jr.): 1 apterous male (DZRJ).

\section{Rhagovelia aiuruoca Moreira \& Ribeiro, 2009}

Rhagovelia aiuruoca is the only member of the obesa group known from South America, and occurs in several medium to high altitude localities on southeastern Brazil. Moreira \& Ribeiro (2009) and Ribeiro et al. (2010) recorded the species from Teresópolis Municipality, Rio de Janeiro, based on material from DZRJ. However, such specimens have not been located in this collection, and the records from Teresópolis are herein considered results of listing errors during the elaboration of those articles. Other records from Rio de Janeiro State are presented below, from areas closer to the type-locality of Itamonte, Minas Gerais State.

Examined material. BRAZIL: Rio de Janeiro - Itatiaia, Parque Nacional do Itatiaia, Córrego Simon, 22²6’11.35”S, 44³6'19.62”W, 15.IV.2007, (L. L. Dumas): 3 apterous males, 4 apterous females (DZRJ); Córrego Maromba, Cachoeira Véu da Noiva, 22²5’38.23”S, 44³7’05.76”W, 
16.IV.2007, (N. Ferreira-Jr., A. P. M. Santos, L. L. Dumas): 14 apterous males, 4 apterous females (DZRJ). Itatiaia, Vale das Cruzes, Rio das Cruzes, 22²0’24.30”'S, 44³5'39.00”'W, 27.IX.2007, (J. L. Nessimian, L. L. Dumas, G. A. Jardim \& A. P. M. Santos): 2 apterous males, 1 apterous females, 2 macropterous females (DZRJ). Itatiaia, Parque Nacional do Itatiaia, afluente do Rio Preto, próximo à Cachoeira do Maromba, 24.XI.2003, (J. L. Nessimian \& A. Huamantinco): 1 apterous male, 1 apterous female (DZRJ).

\section{Rhagovelia elegans Uhler, 1894}

This species was recorded from Rio de Janeiro as $R$. costalimai Drake, 1948, a taxon later considered a synonym of $R$. elegans by Polhemus (1997). Since Drake (1948), no other record from the state has been presented, and the known distribution on the area was restricted to the area surrounding Guapimirim. A new record from another municipality is presented below.

Examined material. BRAZIL: Rio de Janeiro - Macaé, afluente de segunda ordem do Córrego do Ouro, $22^{\circ} 17$ '14.20"S, 42 ${ }^{\circ} 00^{\prime} 14.70$ "W, 16.IV.2009, (V. P. Alecrim): 4 apterous males, 5 apterous females (DZRJ).

\section{Rhagovelia hambletoni Drake \& Harris, 1933}

This species was previously recorded from Minas Gerais and Rio de Janeiro states (Moreira \& Ribeiro 2009), and we now provide new municipality records from São Fidélis, Rio de Janeiro and Parati.

Examined material. BRAZIL: Rio de Janeiro - São Fidélis, SF/lage 1,

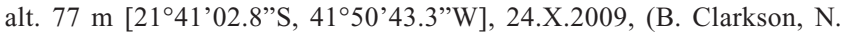
Ferreira-Jr. \& G. Cardoso-Costa): 1 macropterous male (DZRJ). São Fidélis, Rio do Colégio, 21`39’24.80”S, 4140’43.00”W, 24.X.2009, (B. Clarkson \& G. Cardoso-Costa): 1 macropterous male (DZRJ). Macaé, Rio Sana, Barra do Sana, 25-V-1997: 1 apterous male (DZRJ). Macaé, Frade, Córrego, das Pedras, 22 ${ }^{\circ} 14^{\prime} 28.00$ 'S, $42^{\circ} 06^{\prime} 05.70$ 'W, 20.III.2009, (V. P. Alecrim): 2 apterous females (DZRJ). Macaé, BR101, Rio Macaé [22 ${ }^{\circ} 17$ '42,9”S, 4152'48”W], 16.IV.2009, (N. Ferreira-Jr.): 1 apterous female (DZRJ). Itatiaia, Penedo, Três Cachoeiras, 18.XII.2006, (V. P. Alecrim, F. F. F. Moreira \& R. B. Braga): 1 macropterous male (DZRJ). Rio de Janeiro, D. F., (J. C. M. Carvalho): 5 apterous males, 1 macropterous male (MNRJ). Rio de Janeiro, Jacarepaguá, Taquara, (N. Santos): 3 apterous females (MNRJ). Parati, Rio São Roque, 23.V.1992, (Equipe Entomologia): 1 apterous male, 1 apterous female (DZRJ).

\section{Rhagovelia henryi Polhemus, 1997}

Rhagovelia henryi is poorly represented in collections, and known only from a few localities in Rio de Janeiro and São Paulo, Brazil (Moreira \& Barbosa 2011). Its occurrence in the Municipality of Parati, Rio de Janeiro State, is herein reported.

Examined material. BRAZIL: Rio de Janeiro - Parati, Estrada ParatiCunha, tributário do Rio do Sertão, 19.X.2000, (Equipe Entomológica): 1 apterous male (DZRJ).

\section{Rhagovelia lucida Gould, 1931}

Specimens from Macaé Municipality identified by Moreira \& Ribeiro (2009) as $R$. lucida are in fact representatives of $R$. agra. The presence of the former species in that mu- nicipality must, therefore, be ignored. The erroneous record was repeated by Ribeiro et al. (2010). Additional records of $R$. lucida and $R$. agra are presented below.

Examined material. BRAZIL: Rio de Janeiro - Rio de Janeiro, Campo Grande, Represa da Batalha, IX.1986, (H. Cunha): 3 apterous males (DZRJ). Angra dos Reis, Trilha do Ouro, Parque Nacional da Serra da Bocaina, Rio Santo Antônio, 2256’12.46”S, 44³6’49.53”W, 03.X.2007, (R. Mugnai, A L. H. Oliveira \& J. L. Nessimian): 1 macropterous male, 1 macropterous female (DZRJ); (A. L. H. Oliveira \& J. L. Nessimian): 8 apterous males, 4 macropterous males, 4 apterous females, 5 macropterous females (DZRJ). Angra dos Reis, Ilha Grande, Praia da Parnaioca, riacho terceira ordem, estuário, 29.XII.2008, (F. F. F. Moreira): 1 apterous male, 1 apterous female (DZRJ). Mangaratiba, BR-101, Rio Muriqui, 2255'00.00”S, 4357’11.00”W, 18.IX.2007, (D. Baptista, R. Mugnai \& A. L. H. Oliveira): 1 apterous female (DZRJ). Mangaratiba, Rubião, Fazenda Cachoeira do Cedro, 3.II.1959, (Arnaldo \& Alceu): 2 apterous males, 1 apterous female (MNRJ).

\section{Rhagovelia agra Drake, 1957}

Examined material. BRAZIL: Rio de Janeiro - Teresópolis, Serra do Subaio, Rio da Varginha, 10.II.2009: 1 apterous female (DZRJ). Teresópolis, 1950, (J. C. M. Carvalho): 1 apterous male (MNRJ). Macaé, Frade, Córrego das Pedras, 22¹4’28.00”S, 4206’05.70”W, 20.III.2009, (B. H. L. Sampaio): 1 apterous male (DZRJ). Macaé, Curubixás de Cima, tributário do Rio São Pedro, 22॰13'47.60”S, 4208'04.70”W, 20.III.2009, (V. P. Alecrim): 1 apterous male (DZRJ). Macaé, Curubixás de Cima, Rio Curubixás, 22¹1'38.10”S, 4204'26.10”W, 21.III.2009, (G. Lefebrve \& V. P. Alecrim): 27 apterous males, 6 apterous females (DZRJ); tributário do Rio Curubixás, 22 $2^{\circ} 11^{\prime} 38.40^{\prime \prime S}$, 42 $2^{\circ}$ '46.10"W: 2 apterous males, 10 apterous females (DZRJ). Macaé, Glicério, Córrego Boa Sorte, 22¹4’30.40”S, 4205'14.10”W, 22.III.2009, (V. P. Alecrim): 5 apterous males (DZRJ). Macaé, Sana, rio em frente ao camping da ilha, 12.VII.2000: 5 apterous males (DZRJ). Nova Friburgo, Rio São Lourenço, 02.IV.2004: 17 apterous males, 7 apterous females (DZRJ). Nova Friburgo, Lumiar, Rio Boa Vista, tributário Boa Esperança, 04.VIII.2001: 1 apterous male (DZRJ). Nova Friburgo, Lumiar, Rio São José, Cachoeira São José, 22॰14'51.30”S, 42¹7’46.10”W, 13.XI.2008, (V. P. Alecrim): 35 apterous males, 1 macropterous male, 38 apterous females, 7 macropterous females (DZRJ). Nova Friburgo, Lumiar, Córrego da Pedra Vermelha, 22 ${ }^{\circ} 19^{\prime} 01.50$ 'S, 42¹7'23.30”W, 14.XI.2008, (V. P. Alecrim \& I. Gonçalves): 26 apterous males, 12 apterous females, 2 macropterous males, 1 macropterous female (DZRJ); 15.XI.2008, 22²3'57.90”'S, 42¹9'14.60”W: 4 apterous males, 1 apterous female (DZRJ). Nova Friburgo, Lumiar, Córrego da Pedra Riscada, 22²1'46.70”S, 42¹8'34.60”W, 16.XI.2008, (V. P. Alecrim \& J. L. Nessimian): 1 apterous male, 1 apterous female (DZRJ). Nova Friburgo, Lumiar, Córrego Santa Margarida, 22²0'00.00”S, 42¹7'24.10”W, 16.XI.2008, (V. P. Alecrim): 16 apterous males, 15 macropterous males, 6 apterous females, 14 macropterous females (DZRJ). Nova Friburgo, Macaé de Cima, 22²5'27.50”'S, 42³2’08.40”'W, 29.XI.2008, (N. Ferreira-Jr.): 1 apterous male, 6 apterous females, 2 macropterous females (DZRJ); 22॰25'51.90"S, 42॰32'18.90”W, 30.XI.2008: 9 apterous males, 3 macropterous males, 5 apterous females (DZRJ). Nova Friburgo, Fazenda São Sebastião, Rio Bonito, 22²4'18.80”S, 42²7'55.30”W, 01.XII.2008: 17 apterous males, 3 macropterous males, 3 apterous females, 1 macropterous females (DZRJ). Nova Friburgo, Toca da Onça, Córrego dos Patos, 22²4’45.50”S, 42 ${ }^{\circ}$ '9'10.60"W, 08.III.2009, (V. P. Alecrim): 6 apterous males, 4 apterous

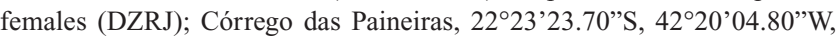
06.III.2009: 1 macropterous male, 1 apterous female (DZRJ) Nova Friburgo, Ramalhete, afluente de terceira ordem do Rio Bonito, 22²4'38.50"S, $42^{\circ} 20^{\prime} 40.70$ 'W, 06.III.2009, (A. L. Henriques-Oliveira \& V. P. Alecrim): 1 macropterous male, 1 brachypterous male, 1 brachypterous 1 apterous female (DZRJ). Nova Friburgo, Rio Bonito, 22²4'46.50”S, 42²4'13.30”'W, 07.III.2009: 1 apterous male, 3 apterous females (DZRJ). Nova Friburgo, Encontro dos Rios, Rio Macaé, 22²3'37.10”'S, 42¹8'20.60”W, 08.III.2009, (V. P. Alecrim): 2 apterous females, 2 apterous females (DZRJ). Nova Friburgo, Cascata, $22^{\circ} 22^{\prime} 03.20^{\prime}$ 'S, $42^{\circ} 15^{\prime} 27.80^{\prime \prime W}$, 08.III.2009, (V. P. Alecrim): 3 apte- 
rous males (DZRJ). Nova Friburgo, Rio Bonito de Cima, Rio Santo Antônio, $22^{\circ} 24$ '15.30”S, 42²6’46.20”W, 04.IV.2009, (V. P. Alecrim): 33 apterous males, 23 apterous females (DZRJ). Nova Friburgo, Rio Bonito de Lumiar, Rio Bonito, 22²4'54.70”'S, 42²5'22.30”W, 04.IV.2009: 10 apterous males, 12 apterous females (DZRJ). Nova Friburgo, Rio das Flores, 22²4’36.30”S, $42^{\circ} 29^{\prime} 40.60^{\prime \prime} \mathrm{W}$, (N. Ferreira-Jr.): 3 apterous males, 3 apterous females (DZRJ); $22^{\circ} 25^{\prime} 36.60 ” S, 42^{\circ} 30^{\prime} 26.40$ ”W, (B. H. L. Sampaio): 2 apterous males, 1 apterous female (DZRJ). Nova Friburgo, tributário Rio Santiago, 25.VIII.2000: 2 apterous females, 1 macropterous female (DZRJ). Nova Friburgo, Macaé de Cima, 22²4'46.00”S, 42³1'16.20”W, 11.IX.2008, (V. P. Alecrim): 8 apterous males, 2 macropterous males, 19 apterous females, 5 macropterous females (DZRJ). Nova Friburgo, Lumiar, Córrego do Poço Feio, 22²1'04.70”S, 42²0’02.70”W, 13.XII.2008, (V. P. Alecrim): 4 apterous males, 6 apterous females, 1 macropterous female (DZRJ). Casimiro de Abreu, Rio Tenal, 25.III.2001, (no collector data): 4 apterous males, 1 apterous female (DZRJ). Cachoeiras de Macacu, Rio Pedra Branca, 24.VIII.2000, (no collector data): 6 apterous males, 3 apterous females, 1 macropterous female (DZRJ). Cachoeiras de Macacu, Rio Gato Preto, 21.V.2011, (no collector data): 1 apterous female (DZRJ). Guapimirim, Rio Iconha, 23.VIII.2000, (no collector data): 4 apterous males, 2 apterous females (DZRJ). Rio de Janeiro, D. F., (J. C. M. Carvalho): 2 apterous male, 1 apterous female (MNRJ).

\section{Rhagovelia macta Drake \& Carvalho, 1955}

Very few representatives of $R$. macta are known, and Moreira \& Ribeiro (2009) and Ribeiro et al. (2010) recorded the species from Rio de Janeiro State based on just two specimens from Nova Friburgo. Such specimens have been checked and in fact correspond to $R$. itatiaiana. The presence of the first species on the state was, however, confirmed by examination of other specimens listed below. Additional records of $R$. itatiaiana in the state are also presented.

Examined material. BRAZIL: Rio de Janeiro - Itatiaia, Parque Nacional do Itatiaia, riacho de primeira ordem no sítio próximo ao Lago Azul, $22^{\circ} 27^{\prime}$ 08.68”S, 44³6'57.10”W, 13.IV.2007, (L. L. Dumas, A. P. M. Santos, J. L. Nessimian \& N. Ferreira-Jr.): 1 apterous male (DZRJ). Casimiro de Abreu, Rio Tenal, 25.III.2001, (no collector data): 2 apterous males (DZRJ). Rio de Janeiro, Água Santa, Morro da Covanca, Várzea Country Clube, 24.V.1991, (E. R. da Silva): 1 apterous male (DZRJ). Campo Grande, Rio da Prata, Represa da Batalha, IX.1986, (H. Cunha): 4 apterous males, 4 apterous females (DZRJ). Jacarepaguá, Parque Estadual da Pedra Branca, Colônia, 26.X.2001, (Equipe Entomologia): 2 apterous females (DZRJ). Jacarepaguá, Pau da Fome, (N. Santos): 1 apterous male (MNRJ).

\section{Rhagovelia itatiaiana Drake, 1953}

Examined material. BRAZIL: Rio de Janeiro - Nova Friburgo, São Pedro da Serra, Córrego Bocaina, 26.X.1991: 1 apterous male, 1 apterous female (DZRJ). Rio de Janeiro, Açude Solidão, IV.1977, (N. Santos): 5 apterous males, 5 apterous females (MNRJ).

\section{Rhagovelia modesta Bacon, 1956}

Rhagovelia modesta is known from a few localities on Rio de Janeiro and São Paulo states, being here recorded from Macaé, Itatiaia, and Nova Friburgo municipalities.

Examined material. BRAZIL: Rio de Janeiro - Macaé, Barra do Sana, 02.VII.2000, (R. M. C. Paiva): 2 apterous females (DZRJ). Itatiaia, Rio Marimbondo, 22॰20’04.90”S, 44³2’31.90”W, 27.IX.2007, (L. L. Dumas \& A. P. M. Santos): 1 apterous male, 4 apterous females (DZRJ). Itatiaia,
Penedo, Três Cachoeiras, 18.XII.2006, (V. P. Alecrim, F. F. F. Moreira \& R. B. Braga): 1 apterous female, 2 macropterous females (DZRJ). Nova Friburgo, Lumiar, Rio Macaé, 22॰21'47.30”S, 42¹8’37.60”W, 15.XI.2008, (V. P. Alecrim): 4 apterous males, 2 apterous females, 5 macropterous males, 3 macropterous females (DZRJ). Nova Friburgo, Lumiar, Rio Boa Vista, tributário Boa Esperança, 04.VIII.2001: 1 apterous female (DZRJ). Nova Friburgo, Macaé de Cima, 22²5'51.90”S, 42³2'18.90”W, 30.XI.2008, (N. Ferreira-Jr.): 1 apterous male (DZRJ). Nova Friburgo, Macaé de Cima, Rio Macaé, ponte, 22²3’29.70”S, 42²9’06.00”W, 01.XII.2008, (B. H. L. Sampaio): 1 macropterous female (DZRJ). Nova Friburgo, Rio Bonito de Cima, Rio Bonito, 22²4'46.50”S, 42²4'13.30”W, 07.III.2009, (V. P. Alecrim): 1 apterous male, 6 apterous females (DZRJ). Nova Friburgo, Encontro dos Rios, Rio Macaé, 22²3’37.10”S, 42¹8'20.60”W, 08.III.2009, (V. P. Alecrim): 6 apterous males, 6 apterous females, 1 macropterous female (DZRJ). Nova Friburgo, Cascata, $22^{\circ} 22^{\prime} 03.20^{\prime}$ 'S, 42 ${ }^{\circ} 15^{\prime} 27.80^{\prime \prime} \mathrm{W}$, 08.III.2009, (V. P. Alecrim): 6 apterous males, 1 macropterous male, 1 apterous female (DZRJ). Nova Friburgo, Macaé de Cima, Rio das Flores, 22॰24’36.30”S, 42²9’40.60”W, 30.XI.2008, (N. Ferreira-Jr.): 9 apterous males, 3 apterous females (DZRJ). Nova Friburgo, Macaé de Cima, $22^{\circ} 24^{\prime} 46.00^{\prime}$ 'S, 42³1'16.20"W, 11.IX.2008, (V. P. Alecrim): 1 apterous male (DZRJ). Nova Friburgo, Lumiar, Córrego do Poço Feio, 22²1'04.70" S, 42²0’02.70"W, 13.XII.2008, (V. P. Alecrim): 1 macropterous male (DZRJ). Nova Friburgo, Rio Bonito, Rio Bonito, atrás da pousada, 22 ${ }^{\circ} 13$ '47.60”S, 4208'04.70”W, 30.X.2009, (G. C. Cardoso): 2 apterous males, 3 apterous females (DZRJ). Rio Claro, Lídice, Rio Piraí, 22॰50’28.00”S, 44¹1'58.00”W, 02.X.2007, (A. L. H. Oliveira \& J. L. Nessimian): 6 apterous males, 27 apterous females (DZRJ); Rio Cotia, 22॰50'08.00"S, 4412'32.00"W: 33 apterous males, 11 apterous females (DZRJ). Angra dos Reis, Perequê, Rio Itapicú, 22 $2^{\circ} 9^{\prime} 10.00^{\prime}$ S, 4432'28.00"W, 03.X.2007: 2 apterous males (DZRJ); Rio Perequê, 2300'25.00"S, 4431'22.00'W: 2 apterous females (DZRJ). Parati, Rio Barra Grande, $23^{\circ} 05^{\prime} 39.00^{\prime}$ 'S, 4442'57.00”W, 03.X.2007, (R. Mugnai, A. L. H. Oliveira \& J. L. Nessimian): 1 apterous female (DZRJ). Parati, Rio São Roque, 2304'36.00”S, 4441'51.00”W, 03.X.2007, (A. L. H. Oliveira \& J. L. Nessimian): 11 apterous males, 6 apterous females (DZRJ).

\section{Rhagovelia novana Drake, 1953}

This species has a geographical distribution ranging from southeastern Brazil to Argentina and Uruguay, and is recorded here for the first time from Itatiaia and Teresópolis municipalities.

Examined material. BRAZIL: Rio de Janeiro - Itatiaia, Rio Marimbondo, 22²0’04.90”S, 44³2’31.90”W, 27.IX.2007, (L. L. Dumas \& A. P. M. Santos): 5 apterous females (DZRJ). Teresópolis, Santa Rita, Ribeirão Santa Rita, Bacia do Rio Paquequer, 863 m, 27.VIII.2010, (P. H. N. Bragança): 1 apterous male (DZRJ). Nova Friburgo, Macaé de Cima, Rio das Flores, 22॰24’36.30”S, 42²9’40.60”W, 30.XI.2008, (N. Ferreira-Jr.): 2 apterous females (DZRJ).

\section{Rhagovelia sooretama Moreira, Nessimian \& Rúdio, 2010}

Rhagovelia sooretama was previously known only from two rivers in the Sooretama Biological Reserve, Espírito Santo (Moreira et al. 2010), and is herein recorded from Rio de Janeiro State.

Examined material. BRAZIL: Rio de Janeiro - Macaé, Rio Macaé, 16.VII.2001, (N. Ferreira-Jr.): 2 apterous males, 1 apterous female (DZRJ); 29.VII.2003: 1 apterous female (DZRJ); 2005: 1 apterous male, 2 apterous females (DZRJ). Cachoeiras de Macacu, Córrego Boa Vista, 03.VIII.2001, (no collector data): 3 apterous males, 1 apterous female (DZRJ) 


\section{Rhagovelia tenuipes Champion, 1898}

This is a widely distributed neotropical species, but with only one previous record from Rio de Janeiro State (Moreira \& Ribeiro 2009). Additional records are presented below.

Examined material. BRAZIL: Rio de Janeiro - São Fidélis, Rio do Colégio, 21³9'24.80”'S, 4140’43.00”W, 24.X.2009, (B. Clarkson \& G. Cardoso-Costa): 12 apterous males, 1 apterous female (DZRJ). Macaé, Frade, Córrego, das Pedras, 22¹4’28.00”S, 4206’05.70”W, 20.III.2009, (V. P. Alecrim): 9 apterous males, 7 apterous females (DZRJ). Macaé, BR101, Rio Macaé [22 ${ }^{\circ} 17^{\prime} 42.9$ 'S, 41 ${ }^{\circ} 52^{\prime} 48^{\prime \prime W}$ ], 16.IV.2009, (N. FerreiraJr.): 1 apterous female (DZRJ). Casimiro de Abreu, Rio Aldeia Velha, 11.VI.2006, (J. L. Nessimian): 5 apterous males (DZRJ). Nova Iguaçu, Rio D’Ouro [-22.64964S, -43.53472W], 07.I.2010, (F. F. F. Moreira \& B. Clarkson): 9 apterous males, 10 apterous females (DZRJ). Mangaratiba, Reserva Ecológica Rio das Pedras, 12.I.1993, (J. L. Nessimian \& E. R. Calil): 5 apterous males, 5 apterous females (DZRJ). Maricá, Rio Ubatiba: 1 apterous female (DZRJ)

\section{Rhagovelia tijuca Polhemus, 1997}

This species was described from Tijuca National Park, and subsequently recorded from some medium altitude localities in São Paulo and Rio de Janeiro by Moreira \& Ribeiro (2009). Additional records are provided below.

Examined material. BRAZIL: Rio de Janeiro - Macaé, Curubixás de Cima, tributário de segunda ordem do Rio Curubixás, $22^{\circ} 11$ '38.40”S, $42^{\circ} 04$ '46.10”'W, 21.III.2009, (G. Lefebrve \& V. P. Alecrim): 1 apterous male (DZRJ). Nova Friburgo, Lumiar, tributário do Rio Santa Margarida, $22^{\circ} 20^{\prime} 35.50^{\prime}$ 'S, $42^{\circ} 18^{\prime} 00.00^{\prime} \mathrm{W}, 16 . X I .2008$, (V. P. Alecrim): 5 apterous males, 4 apterous females (DZRJ). Nova Friburgo, Lumiar, Córrego Santa Margarida, $22^{\circ} 20^{\prime} 00.00^{\prime}$ S, $42^{\circ} 17^{\prime} 24.10^{\prime \prime} \mathrm{W}, 16 . X I .2008$, (V. P. Alecrim): 1

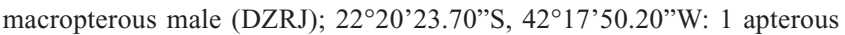
male, 4 apterous females (DZRJ). Nova Friburgo, Fazenda São Sebastião, Rio Bonito, 22 ${ }^{\circ} 24^{\prime} 18.80^{\prime \prime S}, 42^{\circ} 27^{\prime} 55.30^{\prime \prime W}$, 01.XII.2008: 1 apterous female (DZRJ). Nova Friburgo, Toca da Onça, Córrego das Paineiras, 22²3'23.70”S, 42²0’04.80”W, 05-06.III.2009, (B. H. L. Sampaio \& V. P. Alecrim): 2 apterous males, 4 apterous females (DZRJ); Rio Bonito de Lumiar, afluente de primeira ordem do Rio Bonito, 22 24 ’37.90”S, 42²0’42.20”'W, 06.III.2009, (A. L. H. Oliveira): 1 apterous female (DZRJ). Nova Friburgo, Rio Bonito de Lumiar, Rio Bonito, 22²4’54.70”S, 42 ${ }^{\circ} 5^{\prime}$ '22.30"W, 04.IV.2009: 1 apterous female (DZRJ). Nova Friburgo, Lumiar, tributário do Rio Santiago, 22²1'05.60”S, 42²2’31.60"W, 05.IV.2009, (V. P. Alecrim): 13 apterous males, 5 apterous females (DZRJ). Cachoeiras de Macacu, Rodovia RJ-116, meio da serra, riacho, 28.III.1992, (E. R. da Silva \& J. L. Nessimian): 1 apterous male (DZRJ); 01.VI.1992 (E. R. da Silva): 1 apterous male (DZRJ).

\section{Rhagovelia triangula Drake, 1953}

Moreira \& Ribeiro (2009) and Ribeiro et al. (2010) recorded this species from Mangaratiba Municipality, Rio de Janeiro. This record results from mislabelling, and the presence of the species on the cited municipality must be ignored. Additional records from Rio de Janeiro State are presented below.

Examined material. BRAZIL: Rio de Janeiro - Itatiaia, Parque Nacional do Itatiaia, Córrego Simon, 22²5'55.01'S, 44³6’24.96”W, 14.IV.2007, (A. P. M. Santos): 1 apterous male (DZRJ); 22²6’11.35”S, 44³6'19.62”W,
15.IV.2007, (L. L. Dumas): 1 apterous male (DZRJ). Itatiaia, Vale das Cruzes, Rio das Cruzes, 22²0’24.30”S, 44³5'39.00”W, 27.IX.2007, (J. L. Nessimian, L. L. Dumas, G. A. Jardim \& A. P. M. Santos): 25 apterous males, 19 apterous females, 6 macropterous females (DZRJ). Nova Friburgo, Lumiar, Rio Macaé, 22²1’47.30”S, 42¹8’37.60”W, 15.XI.2008, (V. P. Alecrim): 1 apterous male (DZRJ). Nova Friburgo, Macaé de Cima, Rio Macaé, ponte, $22^{\circ} 23^{\prime} 29.70^{\prime}$ S, 42²9’06.00”W, 01.XII.2008, (B. H. L. Sampaio): 1 apterous male (DZRJ). Nova Friburgo, Toca da Onça, Rio

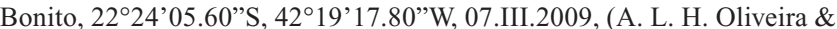
V. P. Alecrim): 1 apterous male, 2 apterous females (DZRJ); Rio Bonito de Cima, Rio Bonito, 22²4’46.50”S, 42²4’13.30”W, 07.III.2009, (A. L. H. Oliveira): 1 apterous female (DZRJ); Encontro dos Rios, Rio Macaé, 2223'37.10”S, 42¹8'20.60”W, 08.III.2009, (V. P. Alecrim): 4 apterous males, 1 apterous females (DZRJ). Nova Friburgo, Cascata, 22 22 '03.20”S, $42^{\circ} 15^{\prime} 27.80$ 'W, 08.III.2009, (V. P. Alecrim): 1 apterous male (DZRJ). Nova Friburgo, Rio Bonito de Lumiar, Rio Bonito, 22 ${ }^{\circ} 24^{\prime} 54.70^{\prime}$ 'S, $42^{\circ} 25^{\prime} 22.30^{\prime}$ " W, 04.IV.2009: 1 apterous female (DZRJ). Rio Bonito, Rio Bonito, atrás da pousada, $22^{\circ} 13$ '47.60”S, 42॰08'04.70”W, 30.X.2009, (G. C. Cardoso): 4 apterous males, 1 apterous female (DZRJ). Itatiaia, Penedo, Três Cachoeiras, 18.XII.2006, (V. P. Alecrim, F. F. F. Moreira \& R. B. Braga): 8 apterous males, 1 apterous female, 4 macropterous females (DZRJ); Cachoeira das 3 Bacias, 30.XII.2006, (F. F. F. Moreira, N. Ferreira-Jr., J. L. Nessimian \& V. P. Alecrim): 11 apterous males, 6 macropterous males, 7 apterous females (DZRJ); 06.III.2008, (J. L. Nessimian, R. B. Braga, M. R. Souza \& L. L. Dumas). 1 apterous female (DZRJ). Guapimirim, Rio Iconha, 23.VIII.2000: 5 apterous males, 1 apterous female (DZRJ).

\section{Rhagovelia trianguloides Nieser \& Melo, 1997}

This species was previously known from Minas Gerais and Espírito Santo (Moreira et al. 2010), and is now recorded for the first time from Rio de Janeiro State.

Examined material. BRAZIL: Rio de Janeiro - Macaé, Glicério, Córrego Boa Sorte, 22¹4’30.40”S, 4205’14.10”W, 22.III.2009, (V. P. Alecrim): 1 apterous female (DZRJ). Itatiaia, Parque Nacional do Itatiaia, riacho de primeira ordem no sítio próximo ao Lago Azul, 22 27'08.68'S 44³6’57.10”W, 13.IV.2007, (L. L. Dumas, A. P. M. Santos, J. L. Nessimian \& N. Ferreira-Jr.): 1 apterous male (DZRJ). Itatiaia, Parque Nacional do Itatiaia, afluente de segunda ordem do Rio Campo Belo, 22 $26^{\circ} 43.82^{\prime \prime S}$, 4436'26.59”W, 15.IV.2007, (L. L. Dumas \& A. P. M. Santos): 7 apterous males (DZRJ). Itatiaia, afluente de primeira ordem do Rio das Cruzes, 2220’25.20”S, 44³5’41.90”W, 27.IX.2007, (G. A. Jardim, L. L. Dumas, A. P. M. Santos \& J. L. Nessimian): 3 apterous females, 1 apterous male (DZRJ). Itatiaia, Penedo, Três Cachoeiras, 18.XII.2006, (V. P. Alecrim, F. F. F. Moreira \& R. B. Braga): 14 apterous males, 8 apterous females, 6 macropterous males, 3 macropterous females (DZRJ); Cachoeira das 3 Bacias [22²4'36.9'S, 44³3'02.7'’W], 30.XII.2006, (F. F. F. Moreira, N. Ferreira-Jr., J. L. Nessimian \& V. P. Alecrim): 15 apterous males, 16 apterous females, 2 macropterous females (DZRJ); 06.III.2008, (J. L. Nessimian, R. B. Braga, M. R. Souza \& L. L. Dumas): 5 apterous males, 1 macropterous male, 9 apterous female (DZRJ).

\section{Rhagovelia vaniniae Moreira, Nessimian \& Rúdio, 2010}

This species was recently described from Espírito Santo, and is recorded here for the first time from Rio de Janeiro State.

Examined material. BRAZIL: Rio de Janeiro - Macaé, Rio Sana em baixo da ponte, 15.VII.2000, (R. M. C. Paiva): 3 apterous females (DZRJ). Itatiaia, Penedo, Três Cachoeiras, 18.XII.2006, (V. P. Alecrim, F. F. F. Moreira \& R. B. Braga): 3 macropterous males (DZRJ). 


\section{Rhagovelia zela Drake, 1959}

This species ranges from Espírito Santo to Santa Catarina (Moreira et al. 2010), and is recorded here for the first time from Rio Claro Municipality, Rio de Janeiro.

Examined material. BRAZIL: Rio de Janeiro - Rio Claro, Lídice, Rio Piraí, 22॰50'28.00”S, 44¹1'58.00”W, 02.X.2007, (J. L. Nessimian \& A. L. H. Oliveira): 26 apterous males, 9 apterous females (DZRJ); Rio Cotia, $22^{\circ} 50$ '08.00”S, 4412'32.00”'W: 2 apterous males, 1 apterous female (DZRJ).

\section{Stridulivelia quadrispinosa (Hungerford, 1929)}

This species was known for a long time only from northern South America, in Peru and Bolivia, but was recently recorded from southeastern Brazil (Moreira et al. 2010). It is recorded here for the first time from Rio de Janeiro State.

Examined material. BRAZIL: Rio de Janeiro - Macaé, Rio Macaé, 16.IV.2002, (N. Ferreira-Jr.): 1 brachypterous female (DZRJ).

\section{ACKNOWLEDGMENTS}

This work was made possible by a scholarship provided by Coordenação de Aperfeiçoamento de Pessoal de Nível Superior (CAPES). We thank Drs. Dan A. Polhemus, for his valuable comments on the taxonomy of Neotropical Rhagovelia; Filippo M. Buzzetti, for his comments on the manuscript; and Gabriel Mejdalani (MNRJ), for providing access to his institution's collection.

\section{REFERENCES}

Andersen, N. M. 1982. The semiaquatic bugs (Hemiptera, Gerromorpha) phylogeny, adaptations, biogeography and classification. Entomonograph 3: $1-455$.

Drake, C. J. 1948. Concerning some tropical Rhagovelia (Hemiptera: Veliidae). Boletín de Entomología Venezolana 7: 141-144.

Frick, K. E. 1949. The biology of Microvelia capitata Guérin, 1857, in the Panama Canal Zone and its role as a predator on anopheline larvae (Veliidae: Hemiptera). Annals of the Entomological Society of America 42: 77-100.
Hecher, C. 2005. Notes on Pseudovelia Hoberlandt (Insecta: Heteroptera: Veliidae) from Thailand, with description of a new species. Annalen des Naturhistorischen Museums Wien 106B: 55-65.

Heckman, C. W. 2011. Encyclopedia of South American Aquatic Insects: Hemiptera-Heteroptera Illustrated Keys to Known Families, Genera, and Species in South America. Springer, 679 p.

Hungerford, H. B. 1919. The biology and ecology of aquatic and semiaquatic Hemiptera. University of Kansas Science Bulletin 11: 1-328.

Mazzucconi, S. A.; M. L. López Ruf \& A. O. Bachmann. 2008. Gerromorpha y Nepomorpha (Insecta: Heteroptera) del Parque Provincial Salto Encantado del Valle del Cuñá Pirú, Provincia de Misiones, Argentina. Lundiana 9: 57-66.

Moreira, F. F. F. \& J. F. Barbosa. 2011. The Veliidae (Hemiptera: Heteroptera: Gerromorpha) from São Paulo State, Brazil: new species, description of the male of Microvelia ioana Drake \& Hottes, 1952, and synonymical and distributional notes. Annales de Limnologie 47: 297-311.

Moreira, F. F. F.; J. L. Nessimian; J. A.; Rúdio \& F. F. Salles. 2010. New species and new records of Veliidae from Espírito Santo State and adjacent Minas Gerais State, Brazil, with notes on nomenclature (Insecta: Heteroptera: Gerromorpha). Journal of Natural History 44: 2761-2801.

Moreira, F. F. F. \& J. R. I. Ribeiro. 2009. Two new Rhagovelia (Heteroptera: Veliidae) and new records for twelve species in Southeastern Brazil. Aquatic Insects 31: 45-61.

Nakasuji, F. \& V. A. Dyck. 1984. Evaluation of the role of Microvelia douglasi atrolineata (Bergroth) (Heteroptera: Veliidae) as predator of the brown planthopper Nilaparvata lugens (Stål) (Homoptera: Delphacidae). Researches on Population Ecology 26: 134-149.

Polhemus, D. A. 1997. Systematics of the genus Rhagovelia Mayr (Heteroptera: Veliidae) in the Western Hemisphere (exclusive of the angustipes complex). Langham, Entomological Society of America, ii $+386 \mathrm{p}$.

Polhemus, J. T. \& D. A. Polhemus. 2007. Global trends in the description of aquatic and semiaquatic Heteroptera species, 1758-2004. Tijdschrift voor Entomologie 150: 271-288.

Polhemus, J. T. \& D. A. Polhemus. 2008. Global diversity of true bugs (Heteroptera: Insecta) in freshwater. Hydrobiologia 595: 379-391.

Ribeiro, J. R. I.; F. F. F. Moreira; V. P. Alecrim; J. F. Barbosa \& J. L. Nessimian. 2010. Espécies de heterópteros dulçaquícolas (Hemiptera, Heteroptera, Gerromorpha e Nepomorpha) registradas no Estado do Rio de Janeiro, Brasil. Arquivos do Museu Nacional 67: 303-312.

Yang, C. M. \& D. H. Murphy. 2011. Guide to the aquatic Heteroptera of Singapore and peninsular Malaysia. 6. Mesoveliidae, with description of a new Nereivelia species from Singapore. Raffles Bulletin of Zoology 59: 53-60.

Zettel, H. 2009. Further new Helotrephini (Insecta: Heteroptera: Helotrephidae) from Vietnam, Malaysia, and the Philippines. Annalen des Naturhistorischen Museums Wien 110B: 33-50. 